Article

\title{
The Beneficiation Processes of Low-Grade Sedimentary Phosphates of Tozeur-Nefta Deposit (Gafsa-Metlaoui Basin: South of Tunisia)
}

\author{
Haïfa Boujlel ${ }^{1,2, *(\mathbb{D}}$, Ghassen Daldoul ${ }^{1,2} \mathbb{C}^{(}$, Haïfa Tlil $^{1,2}{ }^{\text {, Radhia Souissi }}{ }^{2}$, \\ Noureddine Chebbi ${ }^{3}$, Nabil Fattah ${ }^{4}$ and Fouad Souissi ${ }^{1,2}$ \\ 1 Department of Geology, Faculty of Sciences of Tunis, University of Tunis El Manar, Tunis 2092, Tunisia; \\ daldoul.ghassen@yahoo.com (G.D.); haifatlili1@hotmail.fr (H.T.); souissifoued2@gmail.com (F.S.) \\ 2 National Institute of Research and Physico-Chemical Analysis (INRAP), Technopole of Sidi Thabet, \\ Ariana 2020, Tunisia; souissiradhia@yahoo.fr \\ 3 National Office of Mines (ONM), Tunis 2035, Tunisia; noureddine.chebbi23@yahoo.com \\ 4 Research Centre of the Phosphate Company of Gafsa (CPG), Metlaoui 2130, Tunisia; nabil.fattah@cpg.com.tn \\ * Correspondence: boujlelhaifa@yahoo.fr; Tel: +216-95-765-104
}

Received: 22 October 2018; Accepted: 17 December 2018; Published: 20 December 2018

\begin{abstract}
The enrichment of the low-grade-phosphate ore of the Tozeur-Nefta deposit was investigated using scrubbing-attrition, ball grinding and anionic/cationic reverse flotation in order to separate phosphate-rich particles from their gangue. The choice of the beneficiation process was based on the petrographic, mineralogical and chemical analyses. The petrographic and mineralogical studies have revealed the abundance of phosphatic (carbonate-fluorapatite-CFA) particles) coupled with carbonates (calcite, dolomite,) and silicates (quartz, illite, kaolonite) that constitute the (endo/exo) gangue of these ores. Chemical analysis has demonstrated that the raw phosphate sample contains low amounts of $\mathrm{P}_{2} \mathrm{O}_{5}(12.0 \%)$ and $\mathrm{MgO}(4.9 \%)$ and high amounts of $\mathrm{CaO}(40.7 \%)$ and $\mathrm{SiO}_{2}(20.5 \%)$. Microscopic observation/counting has shown that the release mesh occurs in the 71-315 $\mu \mathrm{m}$ size. Scrubbing-attrition, grinding and reverse flotation methods were applied to the $+71 \mu \mathrm{m}$ fraction. Scrubbing-attrition tests of the 71-315 $\mu \mathrm{m}$ fraction have helped to improve the $\mathrm{P}_{2} \mathrm{O}_{5}$ grade to $15.5 \%$. Ball-grinding tests were used to reduce the coarse fraction $+315 \mu \mathrm{m}$. Grounded materials were sieved to $71-315 \mu \mathrm{m}$ and combined with the scrubbed fraction in the flotation feed. Reverse-flotation tests of the phosphate-rich fraction $(71-315 \mu \mathrm{m})$ have helped to improve the $\mathrm{P}_{2} \mathrm{O}_{5}$ grade to $27.1 \%$, with a recovery rate of $92.4 \%$.
\end{abstract}

Keywords: Gafsa-Metlaoui Basin; low-grade phosphate; silicate-carbonate gangue; froth flotation; upgrading

\section{Introduction}

Tunisia is the second largest phosphate producer in Africa, with an annual production of about 8 million tons (Mt) [1,2]. The country also boasts about $1750 \mathrm{Mt}$ of phosphate reserves. The main phosphate resources in Tunisia are distributed over three major Eocene sedimentary basins: the Gafsa-Metlaoui Basin, the Meknessi Basin and the Sra Ouertane Basin [3-6]. The Tozeur-Nefta deposit, which is the subject of the current study, is located in the Southwest region of the Gafsa-Metlaoui Basin, and has remained untapped. In order to upgrade its phosphate-production capacity, the Compagnie des Phosphates de Gafsa (CPG, Tunisia) has planned to make use of the Tozeur-Nefta deposit before 2020. This deposit, which has been the subject of several studies [7-11], contains about $410 \mathrm{Mt}$ of phosphate, has been considered, to date, as a strategic reserve. The majority of the low-grade phosphate ore is organized either in the form of a single layer or a layer-beam including non-phosphatic intercalations [12]. 
Currently, phosphate fertilizers are generally produced from primary-phosphate ores. Phosphate material can easily be separated from the gangue and concentrated by conventional beneficiation techniques (i.e. washing process). As a result of the concurrent increase in demand for phosphate products, and the continuous depletion of phosphate reserves, much more focus is made today on opportunities to recover phosphate ores from secondary sources (i.e. tailings and low-grade ore deposits). These new sources are continually investigated, as is happening now at the Hazara deposit in Pakistan $\left(16 \% \mathrm{P}_{2} \mathrm{O}_{5}\right)$ and the Kohe-lar deposit in Iran $\left(5.01 \% \mathrm{P}_{2} \mathrm{O}_{5}\right)$ [13,14]. Upgrading processes of sedimentary-type phosphate ores consist of separating the gangue minerals (silicates and carbonates) from the valuable phosphate material [15-17]. New processing techniques are needed to upgrade the low-grade phosphates to commercial-grade products $\left(\mathrm{P}_{2} \mathrm{O}_{5}>28 \%\right)$ [18]. The choice of the suitable beneficiation process requires a good knowledge of the mineral assemblages of the studied ore [19]. Several industrial processes are used worldwide for the enrichment of phosphate ores, ranging from simple mechanical preparation to more complex treatment schemes, which combine several methods such as flotation, magnetic, electrostatic and dense-media separation (DMS). Calcination is applied for the enrichment of phosphates that are rich in organic materials, like those of the Youssoufia deposit in Morocco [12], or that include a carbonated gangue, like those of Akashart's phosphates in Iraq [20]. Electromagnetic separation is used mainly for the valorization of igneous phosphates, such as that of the Phalaborawa deposit in South Africa [21]. Acid leaching is a process of enrichment of siliceous and calcareous phosphate ore applied to the Abbotabad deposit in Pakistan [22,23]. Magnetic separation is used to separate magnetic minerals from phosphate ore of the feebly magnetic ankerite, as noted in the Abu Tartur phosphate ore deposit of Egypt [24]. Practically speaking, crushing, grinding and screening methods are used to remove coarse-textured materials. These techniques are also used in the large phosphate-ore deposits of Kef Eddour and Oum El Khecheb, located in the Tunisian Gafsa-Metlaoui Basin $[25,26]$. Generally, washing, attrition and desliming methods are used to remove the major part of the clay-type binder [27].

Flotation is the most widely used method for the enrichment of medium-grade phosphate rock. This method is mainly employed for the separation of phosphate minerals from silicate gangue [28,29]. Flotation may be conducted in of two ways depending on the composition of the material to be processed: direct flotation and/or reverse flotation. That is to say, direct flotation consists of floating the phosphate minerals and depressing the gangue material, while reverse flotation consists of floating the gangue minerals and keeping the phosphatic matter in the slurry. Direct flotation is less effective in the presence of carbonated gangue because of similar physicochemical properties between phosphate and carbonate minerals [28]. Reverse flotation is the most common method used for the separation of phosphate minerals from carbonated gangue [30].

Several studies on reverse-flotation of phosphates with siliceous and carbonated gangues showed satisfactory results in terms of grade and recovery of $\mathrm{P}_{2} \mathrm{O}_{5}[14,26,31-36]$. Reverse flotation can be applied as unique process for the beneficiation of sedimentary siliceous carbonate phosphates, such as those of Ayata (Tunisia) [31] and Sebaiya (Egypt) [33]. It can be preceded by other techniques including grinding (e.g. igneous phosphates of kola (Brazil) [32] and sedimentary phosphates of Kef-Eddur (Tunisia) [26]) and gravity separation followed by direct flotation (e.g. phosphate ore slime of Yichang (China) [36]). Other flotation parameters have been studied; the most important are release mesh, flotation reagents type/dosage, and $\mathrm{pH}$ and pulp concentration. The present work differs from previous studies by in the following way: (i) release mesh, (ii) processes that precede flotation (sizing, washing, attrition and ball milling), (iii) two reverse flotation stages, although used by others, it was performed in this work under specific conditions of $\mathrm{pH}$, reagents type/dosage and air flow-rate.

The present study consists of characterizing the low-grade sedimentary phosphate ore of the roof series of the Tozeur-Nefta deposit, while having for objectives: (i) the examination of the mineralogical and geochemical characteristics of the studied phosphate ore, and (ii) the design of an efficient and economic process for the beneficiation of low-grade phosphate ores, including siliceous and carbonated gangues. 


\section{Materials and Methods}

\subsection{Sampling and Separation}

The trench sampling method was used to extract $400 \mathrm{~kg}$ of raw phosphate material from the roof series of the Tozeur-Nefta deposit. All samples were crushed using a jaw crusher to $100 \%$ below $10 \mathrm{~mm}$ in size, then homogenized and divided by a riffle-sample divider to obtain representative sub-samples, each one weighing $2 \mathrm{~kg}$. After further quartering, one sub-sample was ground manually in an agate mortar into a fine powder for XRD and chemical analysis. One of the non-ground sub-samples was used for grain-size analysis as well as for microscopic observation. The remaining sub-samples were stored in plastic bags for phosphate beneficiation process.

\subsection{Analysis}

A representative sub-sample from the roof phosphate layer of the Tozeur-Nefta deposit was used in this study to conduct the mineralogical and geochemical grain-size analyses.

\subsubsection{Petrographic and Mineralogical Analysis}

The petrographic analysis was carried out by means of thin sections, which were examined and photographed with an optical microscope. Mineralogical characterization was carried out on the basis of an XRD analysis and binocular observation methods. XRD analyses were carried out by means of PANalytical X'Pert PRO X-ray diffractometer (Cu K $\alpha$ radiation; $\lambda=1.5418 \AA$, PANalytical, Almelo, The Netherland). Mineralogical identification was performed by means of High Score Plus software (version 2.1, PANalytical, Almelo, The Netherland) equipped with the ICDD PDF-2 Release 2004.

\subsubsection{Particle-Size Analysis and Heavy-Liquid Separation}

Particle-size distribution was measured by means of the wet-sieve (AFNOR) method (from 0.40 to $10 \mathrm{~mm}$ size range). Binocular observation of the different size fractions of the sample was used to identify and quantify, by visual inspection and grain counting, the relative percentages of the major minerals, and to evaluate the release mesh of phosphate minerals. Dense media separation was evaluated at laboratory scale through heavy-liquid separation (HLS) test work. Tetra Bromo Ethane $\left(\mathrm{TBE}\right.$, density $\left.(\mathrm{d})=2.96 \mathrm{~g} / \mathrm{cm}^{3}\right)$ was used to separate phosphate minerals $\left(\mathrm{d}>2.96 \mathrm{~g} / \mathrm{cm}^{3}\right)$ from silicate and carbonated gangue minerals $\left(\mathrm{d}<2.96 \mathrm{~g} / \mathrm{cm}^{3}\right)$. Phosphate fraction was dried and examined by binocular observation in order to manually sort phosphate grains from the remaining impurities.

\subsubsection{Chemical Analysis}

Chemical and analytical procedures, applied to the studied phosphate material, as considered in the present study, are adapted from the protocols of CPG and tested in the company's labs, where standardized methods are used specifically for total digestion and chemical analysis of sedimentary phosphate rocks. $\mathrm{P}_{2} \mathrm{O}_{5}$ and $\mathrm{CaO}$ were analyzed by colorimetry (Technicon Auto-analyzer, Bran-Luebbe, SPX Process Equipment, Norderstedt, Germany) after digestion by $\mathrm{HClO}_{4}-\mathrm{HCl}$. Atomic adsorption spectroscopy (Perkin Elmer-AAnalyst 800, Perkin Elmer, Norwalk, CT, USA) was used to analyze $\mathrm{MgO}, \mathrm{Fe}_{2} \mathrm{O}_{3}, \mathrm{Al}_{2} \mathrm{O}_{3}, \mathrm{Cu}, \mathrm{Zn}, \mathrm{Mn}$ and $\mathrm{Ni}$ after digestion by $\mathrm{HClO}_{4}-\mathrm{HF}-\mathrm{HNO}_{3}, \mathrm{SiO}_{2}$ after digestion by $\mathrm{HCl}-\mathrm{HF}$ and $\mathrm{Cd}$ after digestion by $\mathrm{HNO}_{3}$. $\mathrm{K}_{2} \mathrm{O}$ and $\mathrm{Na}_{2} \mathrm{O}$ were analyzed by flame spectrometry after digestion by $\mathrm{HClO}_{4}-\mathrm{HF}-\mathrm{HNO}_{3} \cdot \mathrm{SO}_{3}$ was analyzed by gravimetry after digestion by $\mathrm{HCl}$ and subsequent precipitation of $\mathrm{SO}_{4}{ }^{2-}$ ions as $\mathrm{BaSO}_{4}$, with a $\mathrm{BaCl}_{2}$. Loss-on-ignition (LOI) was determined by means of a muffle furnace at $1050{ }^{\circ} \mathrm{C}$. To verify accuracy, standard reference phosphate material SRM694 (Western phosphate rock) and SRM120C (Florida phosphate rock) were digested and analyzed according to the same protocol applied to the phosphate material considered in this study. All chemical analyses presented experimental errors of less than $5 \%$. 


\subsection{Beneficiation Processes}

Beneficiation will be conducted to upgrade the $+71 \mu \mathrm{m}$ size fraction by means of sizing, scrubbing-attrition, grinding and flotation methods.

\subsubsection{Sizing, Scrubbing (Washing) and Attrition}

Scrubbing treatment of raw phosphate $(2 \mathrm{~kg})$ was carried out for $15 \mathrm{~min}(70 \mathrm{rpm})$ and by using a 10-L scrubber and with $40 \%$ solids in order to remove clay impurities from the surface of grains. After scrubbing, the resulting pulp was wet-sieved (AFNOR sieves, see Section 2.2.2) to obtain the 71-315 $\mu \mathrm{m}$ fraction and then subjected to attrition in order to remove further clay coatings from phosphate grains. An attrition step was conducted in a Denver cell at $60 \%$ solid/liquid ratio, respectively, and $1500 \mathrm{rpm}$ $(5,10$ and $15 \mathrm{~min})$. The product from attrition was wet-sieved to eliminate the fraction $-71 \mu \mathrm{m}$ and the 71-315 $\mu \mathrm{m}$ fraction was used as a flotation feed.

\subsubsection{Grinding}

In general, the grinding of ores may lead to the liberation of the valuable minerals from the gangue. It is obvious that wet grinding often requires less energy than dry grinding [37]. The wet-grinding process was investigated for the $+315 \mu \mathrm{m}$ fraction in order to improve the liberation of phosphate grains from the gangue and to make this coarse fraction more suitable for flotation. The characteristics of grinding charge are displayed in Table 1. Steel balls of four types (B1, B2, B3 and B4), of different diameters and weights were used in the study. The large balls are suitable for the fractionation of coarse grains and small balls for small grains [38]. A grinding process was carried out in a ball mill of 10-L capacity. The influence of three grinding parameters on the product fineness was studied and optimized: (i) solid concentration (30\%, 40\% and 50\%), (ii) grinding time (3, 4 and $5 \mathrm{~min}$ ) and (iii) charge ratio $(3 / 1,4 / 1$ and $5 / 1)$ (Table 1$)$. The rotation speed was fixed at $50 \mathrm{rpm}$.

Table 1. Characteristics of grinding balls.

\begin{tabular}{cccc}
\hline Grinding Ball & Diameter (mm) & Ball Ratio (\%) & Weight (kg) \\
\hline B1 & 40 & 7.06 & 0.29 \\
B2 & 30 & 55.5 & 0.12 \\
B3 & 25 & 8.91 & 0.07 \\
B4 & 20 & 28.5 & 0.04 \\
\hline
\end{tabular}

\subsubsection{Flotation}

Reverse flotation was carried out by means of two flotation reagents kindly supplied by Clariant ${ }^{\circledR}$ Company (Shanghai, China): (i) V2711 Flotinor ([R-O- $\left.\left(\mathrm{CH}_{2}\right)_{3}-\mathrm{NH}_{3}\right]+\mathrm{CH}_{3} \mathrm{COO}-$; anionic collector) was used as calcite collector and (ii) Ether diamine Flotigam 2835-2L ([R-O- $\left(\mathrm{CH}_{2}\right)_{3}-$ $\left.\mathrm{NH}-\left(\mathrm{CH}_{2}\right)_{3}-\mathrm{NH}_{3}\right]+\mathrm{CH}_{3} \mathrm{COO}-$; cationic collector) as quartz collector [39-41]. Fresh solutions of these reagents were prepared daily to be used in flotation tests. Dilute $\mathrm{H}_{3} \mathrm{PO}_{4}(5 \%)$ acted both as phosphate depressant and $\mathrm{pH}$-modifier. Reverse flotation tests were performed in a laboratory Denver $1.5 \mathrm{~L}$ flotation cell (model D-12). For each flotation test, a $500 \mathrm{~g}$ of phosphate sample was used. The dilution of the pulp was fixed at $35 \%$ solid, rotation speed at $1500 \mathrm{rpm}$ and air flow-rate at $5.4 \mathrm{~L} / \mathrm{min}$. Phosphate is recovered after two stages of reverse flotation: first, separating phosphate from silicate gangue minerals in natural $\mathrm{pH}(\mathrm{pH}=7.8)$ by means of cationic and anionic collectors, and then, by means of anionic and $\mathrm{H}_{3} \mathrm{PO}_{4}$ reagents in acid medium $(\mathrm{pH}=5.0)$ to separate phosphate from carbonate minerals. Under acid condition, phosphate minerals are not taken up by the foams and remain in the cell. 


\section{Results and Discussion}

\subsection{Petrographic Analysis}

The most abundant phosphatic elements are displayed as rounded to sub-rounded pellets embedded in microsparitic cement (Figure 1a). These elements are often surrounded by a thin and clear cortex (Figure 1b). Other elements were observed in thin sections, such as bone debris of elongated shapes (Figure 1c) and ooliths formed by growth and crystallization of micrometric phosphate layers (Figure 1d). Aggregates of small dolomitic rhombohedra (Figure 1e) constitute the carbonated bonding phase, which generally indicates the beginning of crystallization of the micritic material containing all the impurities of the original mud. The exogangue is generally carbonated, showing phosphate grains surrounded by dolomite rhombohedra (Figure 1f), while the endogangue is present either as silica (Figure 1g) or carbonate grains (Figure 1h), occurring, respectively, as quartz or calcite included within the phosphate grains.
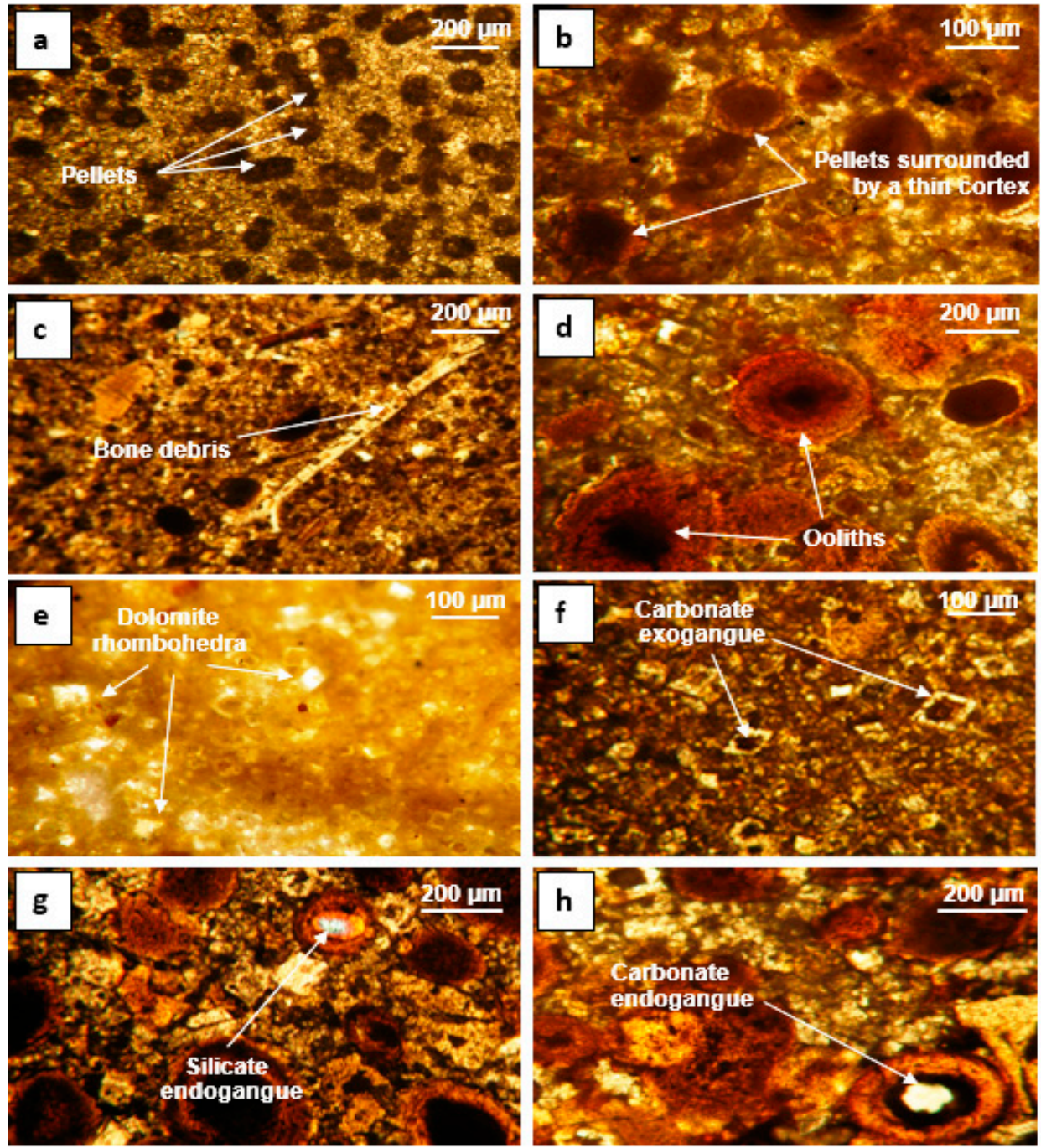

Figure 1. Optical microscope observation (plane polarized light) of the roof phosphates of the Tozeur-Nefta deposit. (a) Pellets of rounded to sub-rounded shapes bound by a microsparitic cement; (b) Pellets surrounded by a thin clear cortex; (c) Bone debris of elongated forms; (d) Oolites formed by the deposition of successive micrometric layers of phosphate; (e) Carbonate bonding phase formed by euhedral dolomite; (f) Carbonate exogangue made of euhedral dolomite; (g) Silicate (quartz) endogangue making the nucleus of the phosphate grain; (h) Carbonate (calcite) endogangue making the nucleus of the phosphate grain. 


\subsection{Mineralogical Analysis}

The XRD pattern (Figure 2) revealed the presence of seven mineral species, as follows: carbonatefluorapatite (CFA), calcite, dolomite, illite, kaolinite, gypsum, and quartz. The binocular observation revealed (Figure 3) the abundance of phosphate elements in the 71-315 $\mu \mathrm{m}$ fractions, carbonate minerals are more concentrated in the $-200 \mu \mathrm{m}$ fraction, whereas free silica is mainly concentrated in the $-160 \mu \mathrm{m}$ fraction. The mixed grains are concentrated in the coarse fraction $(+315 \mu \mathrm{m})$. The release mesh was defined by Blazy [42], as the size that the grains should have for the best detachment of ore particles from the gangue (mixed grain $\leq 10 \%$ ). The release mesh of phosphate grains, determined by binocular microscope, corresponds to the $71-315 \mu \mathrm{m}$ fractions (Figure 3).

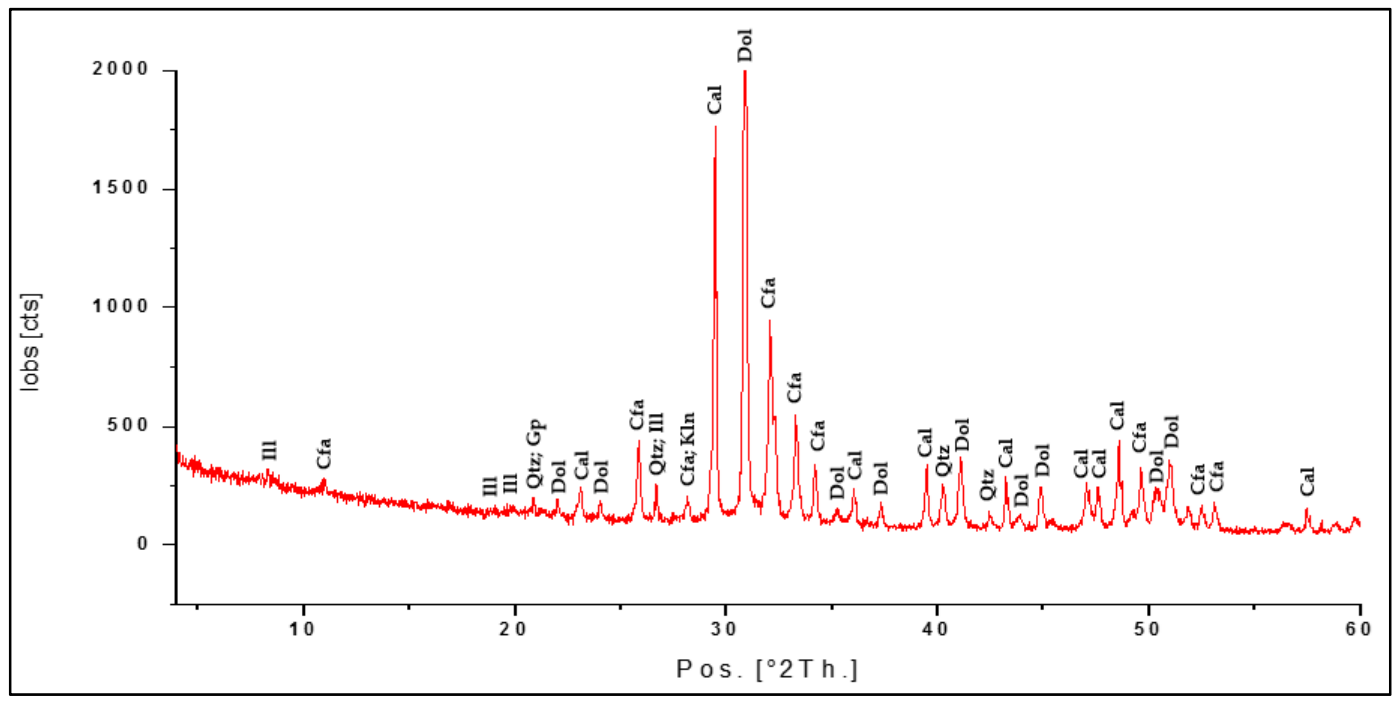

Figure 2. X-ray diffractogram of the raw phosphate sample showing the presence of: carbonatefluorapatite (Cfa), calcite (Cal), dolomite (Dol), illite (Ill), kaolinite (Kln), gypsum (Gp) and quartz (Qtz).

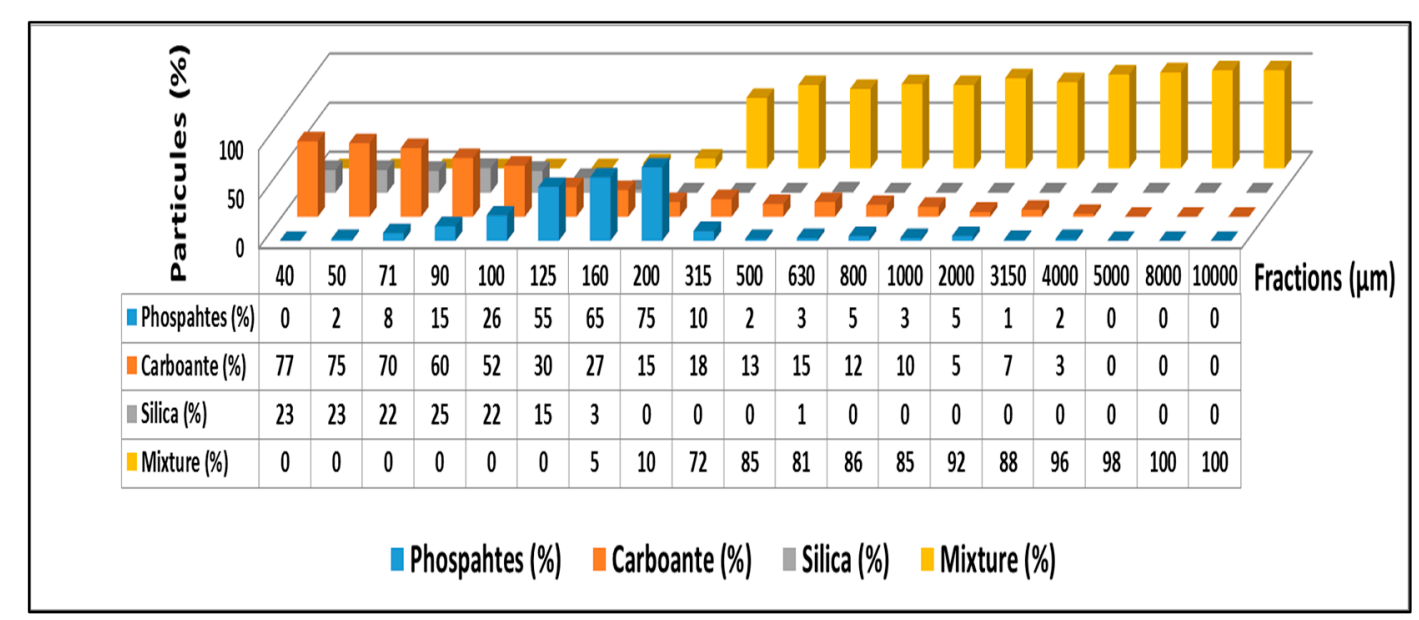

Figure 3. Distribution of the main minerals in different size fractions of the raw phosphate sample.

\subsection{Chemical Analysis}

\subsubsection{Raw Phosphate Analysis}

Chemical analysis (Table 2) has shown a low concentration of $\mathrm{P}_{2} \mathrm{O}_{5}(12.0 \%)$ in the representative phosphate sample of the roof series of Tozeur-Nefta deposit. It is worth noting that phosphate ores can be classified into three groups depending on their $\mathrm{P}_{2} \mathrm{O}_{5}$ content [43]: (i) high-grade phosphate ore (26 to $35 \% \mathrm{P}_{2} \mathrm{O}_{5}$ ), (ii) moderately low-grade phosphate ore (17 to $25 \% \mathrm{P}_{2} \mathrm{O}_{5}$ ), and (iii) low-grade 
phosphate ore (12 to $16 \% \mathrm{P}_{2} \mathrm{O}_{5}$ ). According to this classification, the phosphate ore of the top series of the Tozeur-Nefta deposit belongs to the class of low-grade phosphate. The $\mathrm{CaO} / \mathrm{P}_{2} \mathrm{O}_{5}$ ratio (3.39) is much higher than that of pure CFA (1.55) [4-6]. The concentration of $\mathrm{SiO}_{2}$ was very high $(20.5 \%)$. The concentration of $\mathrm{Fe}_{2} \mathrm{O}_{3}$ and $\mathrm{Al}_{2} \mathrm{O}_{3}$ amounting $0.65 \%$ and $1.75 \%$, respectively, give a ratio $\left(\left(\mathrm{Fe}_{2} \mathrm{O}_{3}+\right.\right.$ $\left.\mathrm{Al}_{2} \mathrm{O}_{3}\right) / \mathrm{P}_{2} \mathrm{O}_{5}$ ) of 0.2. It is worth noting that for values $>0.1$, concentrations of $\mathrm{Fe}_{2} \mathrm{O}_{3}$ and $\mathrm{Al}_{2} \mathrm{O}_{3}$ are considered as high and, therefore, many problems can arise during the filtration and purification of phosphoric acid [44]. Organic-matter $\left(0.28 \%\right.$ organic carbon), $\mathrm{Na}_{2} \mathrm{O}(0.39 \%)$ and $\mathrm{K}_{2} \mathrm{O}(0.45 \%)$ contents are relatively low.

Results of trace elements concentrations are provided in Table 2. The measured Ni $(80 \mathrm{mg} / \mathrm{kg})$, $\mathrm{Zn}(215 \mathrm{mg} / \mathrm{kg}), \mathrm{Cd}(65 \mathrm{mg} / \mathrm{kg}), \mathrm{Cu}(31 \mathrm{mg} / \mathrm{kg})$ and $\mathrm{Mn}(296 \mathrm{mg} / \mathrm{kg})$ concentrations are in agreement with their equivalents in the unwashed (raw) economic ores from the main phosphate series of the Gafsa-Metlaoui basin [1,4,5,45,46].

Table 2. Concentrations of major and trace elements in the studied raw phosphate.

\begin{tabular}{cc}
\hline Element & Concentration \\
\hline $\mathrm{P}_{2} \mathrm{O}_{5}(\%)$ & 12.0 \\
$\mathrm{CaO}(\%)$ & 40.7 \\
$\mathrm{MgO}(\%)$ & 4.95 \\
$\mathrm{SiO}_{2}(\%)$ & 20.5 \\
$\mathrm{SO}_{3}(\%)$ & 1.27 \\
$\mathrm{Fe}_{2} \mathrm{O}_{3}(\%)$ & 0.65 \\
$\mathrm{Al}_{2} \mathrm{O}_{3}(\%)$ & 1.75 \\
$\mathrm{Na}_{2} \mathrm{O}(\%)$ & 0.39 \\
$\mathrm{~K}_{2} \mathrm{O}(\%)$ & 0.45 \\
$\mathrm{Corg}(\%)$ & 0.28 \\
$\mathrm{~F}(\%)$ & 1.27 \\
$\mathrm{CO}$ & 20.2 \\
$\mathrm{LOI}$ & 20.7 \\
$\mathrm{Cd}(\mathrm{mg} / \mathrm{kg})$ & 65 \\
$\mathrm{Cu}(\mathrm{mg} / \mathrm{kg})$ & 31 \\
$\mathrm{Zn}(\mathrm{mg} / \mathrm{kg})$ & 215 \\
$\mathrm{Mn}(\mathrm{mg} / \mathrm{kg})$ & 296 \\
$\mathrm{Ni}(\mathrm{mg} / \mathrm{kg})$ & 80 \\
\hline
\end{tabular}

\subsubsection{Granulo-Chemical Analysis}

The chemical characteristics of the different size fractions of the phosphate sample are shown in Table 3. Results show that the $+125-500 \mu \mathrm{m}$ and the $-40 \mu \mathrm{m}$ fractions $(24.3 \%$ and $38.8 \%$ by weight, respectively) bear the highest amounts in CFA (21.5-11.3\% and $13.2 \% \mathrm{P}_{2} \mathrm{O}_{5}$, respectively). All the fractions analyzed are rich in carbonate minerals ( $\mathrm{CaO}$ concentrations vary from 35.5 to $50.7 \%)$. $\mathrm{MgO}$ is concentrated in the coarse fraction $(+500 \mu \mathrm{m})$ and particles of the $-125 \mu \mathrm{m}$. The fraction $(-40 \mu \mathrm{m})$ is richer in $\mathrm{SiO}_{2}, \mathrm{Fe}_{2} \mathrm{O}_{3}, \mathrm{Al}_{2} \mathrm{O}_{3}$ and $\mathrm{K}_{2} \mathrm{O}$ than all others (Table 3), which shows that clay minerals are, besides carbonates, among the dominant components of the fine fraction, and that most of $\mathrm{SiO}_{2}$ is bound to clay minerals. Due to these results, scrubbing and attrition processes may be used in order to remove the major part of slimes and clay coatings, as well as to upgrade the phosphate ore. The trace element concentrations of the different size fractions are presented in Table 4. Results showed that the fine fraction $(-40 \mu \mathrm{m})$ is richer in $\mathrm{Cu}$ and $\mathrm{Zn}$ than the others. $\mathrm{Cd}$ is concentrated mainly in the coarse fraction $(+200 \mu \mathrm{m})$. 
Table 3. Chemical results of major elements in different size fractions of the studied raw phosphate.

\begin{tabular}{|c|c|c|c|c|c|c|c|c|c|c|c|c|c|c|c|}
\hline $\begin{array}{l}\text { Fraction } \\
(\mu \mathrm{m})\end{array}$ & $\begin{array}{c}\text { Weight } \\
\text { (\%) }\end{array}$ & $\begin{array}{c}\mathrm{P}_{2} \mathrm{O}_{5} \\
(\%)\end{array}$ & $\begin{array}{c}\mathrm{CaO} \\
(\%)\end{array}$ & $\begin{array}{l}\mathrm{CaO} / \\
\mathrm{P}_{2} \mathrm{O}_{5}\end{array}$ & $\begin{array}{c}\mathrm{MgO} \\
(\%)\end{array}$ & $\begin{array}{c}\mathrm{SiO}_{2} \\
(\%)\end{array}$ & $\begin{array}{l}\mathrm{SO}_{3} \\
(\%)\end{array}$ & $\begin{array}{c}\mathrm{Fe}_{2} \mathrm{O}_{3} \\
(\%)\end{array}$ & $\begin{array}{c}\mathrm{Al}_{2} \mathrm{O}_{3} \\
(\%)\end{array}$ & $\begin{array}{c}\mathrm{Na}_{2} \mathrm{O} \\
(\%)\end{array}$ & $\begin{array}{c}\mathrm{K}_{2} \mathrm{O} \\
(\%)\end{array}$ & $\begin{array}{c}\text { Corg } \\
(\%)\end{array}$ & $\begin{array}{l}\mathrm{CO}_{2} \\
(\%)\end{array}$ & $\begin{array}{c}F \\
(\%)\end{array}$ & LOI \\
\hline 10,000 & 4.64 & 4.25 & 47.3 & 11.1 & 3.93 & 17.0 & 0.57 & 0.43 & 1.10 & 0.18 & 0.10 & 0.10 & 23.4 & 1.74 & 25.0 \\
\hline 8000 & 2.11 & 4.63 & 45.1 & 9.74 & 4.55 & 15.6 & 0.54 & 0.49 & 1.24 & 0.17 & 0.11 & 0.12 & 25.8 & 1.74 & 27.5 \\
\hline 5000 & 2.50 & 5.16 & 44.2 & 8.56 & 3.99 & 18.5 & 0.61 & 0.41 & 1.20 & 0.19 & 0.11 & 0.34 & 23.3 & 2.24 & 25.4 \\
\hline 4000 & 0.78 & 5.53 & 46.2 & 8.36 & 3.67 & 16.6 & 0.67 & 0.47 & 1.20 & 0.19 & 0.10 & 0.04 & 23.7 & 2.04 & 25.2 \\
\hline 3150 & 0.89 & 6.89 & 44.2 & 6.42 & 3.34 & 18.0 & 0.75 & 0.36 & 1.14 & 0.21 & 0.10 & 0.24 & 22.7 & 2.60 & 24.59 \\
\hline 2000 & 1.25 & 7.95 & 45.4 & 5.71 & 3.17 & 18.2 & 0.86 & 0.38 & 1.10 & 0.23 & 0.10 & 0.21 & 20.2 & 1.20 & 22.1 \\
\hline 1000 & 1.92 & 8.83 & 45.7 & 5.17 & 3.15 & 17.9 & 1.23 & 0.28 & 1.09 & 0.23 & 0.10 & 0.24 & 19.1 & 2.40 & 21.0 \\
\hline 800 & 1.06 & 8.42 & 46.4 & 5.51 & 2.49 & 17.7 & 1.09 & 0.29 & 1.11 & 0.22 & 0.10 & 0.10 & 20.2 & 3.36 & 21.9 \\
\hline 630 & 1.25 & 8.27 & 46.4 & 5.61 & 1.35 & 17.9 & 1.10 & 0.34 & 1.10 & 0.24 & 0.12 & 0.38 & 20.9 & 3.44 & 23. 9 \\
\hline 500 & 2.02 & 9.56 & 46.8 & 4.89 & 3.13 & 17.1 & 1.14 & 0.35 & 1.09 & 0.39 & 0.11 & 0.37 & 17.4 & 3.12 & 19.5 \\
\hline 315 & 6.05 & 16.8 & 49.6 & 2.94 & 2.21 & 16.3 & 1.67 & 0.41 & 1.03 & 0.57 & 0.10 & 0.42 & 9.09 & 2.72 & 11.3 \\
\hline 200 & 9.99 & 21.5 & 50.7 & 2.36 & 1.53 & 11.3 & 2.03 & 0.29 & 0.95 & 0.73 & 0.09 & 0.49 & 8.56 & 2.44 & 10.9 \\
\hline 160 & 2.31 & 18.9 & 49.8 & 2.64 & 2.06 & 16.5 & 1.8 & 0.19 & 0.94 & 0.59 & 0.09 & 0.16 & 7.38 & 2.00 & 9.16 \\
\hline 125 & 3.94 & 11.3 & 45.5 & 4.04 & 3.66 & 13.8 & 1.13 & 0.26 & 0.91 & 0.43 & 0.11 & 0.24 & 20.9 & 3.32 & 22.8 \\
\hline 100 & 3.75 & 6.86 & 39.9 & 5.81 & 5.25 & 16.3 & 0.79 & 0.24 & 0.91 & 0.33 & 0.11 & 0.12 & 26.6 & 2.52 & 28.3 \\
\hline 90 & 1.92 & 6.26 & 36.6 & 5.85 & 4.56 & 19.6 & 0.73 & 0.19 & 1.10 & 0.32 & 0.12 & 0.19 & 28.3 & 0.73 & 30.1 \\
\hline 71 & 7.11 & 6.11 & 35.8 & 5.86 & 6.82 & 21.3 & 0.66 & 0.15 & 0.96 & 0.22 & 0.13 & 0.30 & 25.4 & 0.66 & 27.4 \\
\hline 50 & 5.77 & 5.26 & 37.8 & 7.19 & 7.21 & 16.9 & 0.63 & 0.20 & 0.82 & 0.25 & 0.08 & 0.48 & 28.5 & 0.63 & 30.9 \\
\hline 40 & 1.92 & 5.43 & 38.5 & 7.09 & 7.19 & 15.8 & 0.68 & 0.24 & 0.86 & 0.20 & 0.08 & 0.12 & 29.2 & 0.68 & 30.9 \\
\hline-40 & 38.8 & 13.2 & 35.5 & 2.68 & 5.62 & 22.5 & 1.33 & 0.85 & 3.35 & 0.42 & 1.07 & 0.28 & 15.1 & 1.33 & 17.1 \\
\hline
\end{tabular}


Table 4. Concentrations $(\mathrm{mg} / \mathrm{kg}$ ) of metallic trace elements in different size fractions of the studied raw phosphate.

\begin{tabular}{cccccc}
\hline Fraction $(\boldsymbol{\mu m})$ & $\mathbf{C d}$ & $\mathbf{C u}$ & $\mathbf{Z n}$ & $\mathbf{M n}$ & $\mathbf{N i}$ \\
\hline 10,000 & 95 & 31 & 148 & 574 & 77 \\
8000 & 129 & 27 & 157 & 589 & 134 \\
5000 & 102 & 26 & 138 & 486 & 97 \\
4000 & 108 & 30 & 151 & 492 & 127 \\
3150 & 82 & 24 & 146 & 544 & 106 \\
2000 & 93 & 22 & 151 & 530 & 143 \\
1000 & 98 & 19 & 113 & 522 & 88 \\
800 & 104 & 22 & 112 & 575 & 144 \\
630 & 110 & 21 & 112 & 613 & 138 \\
500 & 103 & 27 & 120 & 621 & 142 \\
315 & 106 & 27 & 110 & 439 & 133 \\
200 & 80 & 22 & 85 & 340 & 93 \\
160 & 67 & 27 & 84 & 378 & 21 \\
125 & 76 & 23 & 95 & 418 & 58 \\
100 & 57 & 19 & 91 & 296 & 116 \\
90 & 47 & 20 & 84 & 253 & 66 \\
71 & 40 & 15 & 80 & 220 & 70 \\
50 & 40 & 15 & 79 & 211 & 68 \\
40 & 45 & 17 & 83 & 236 & 63 \\
-40 & 49 & 49 & 345 & 173 & 87 \\
\hline
\end{tabular}

\subsection{Enrichment Methods}

As described in the material and methods section, only the $+71 \mu \mathrm{m}$ size fraction was processed by different methods in order to obtain a phosphate-rich fraction $(71-315 \mu \mathrm{m})$ that is suitable for the flotation process. It is worth noting that the $40-71 \mu \mathrm{m}$ fraction was subjected to direct and reverse flotation tests in order to assess the flotation performance of phosphate minerals in the fraction below $71 \mu \mathrm{m}$. The reverse-flotation test (using the same flowsheet used for the $71-315 \mu \mathrm{m}$ fractions) was not successful and no stable foam was observed. Direct flotation ( $2 \mathrm{~min}$ ) of phosphate minerals using a mixture of $1000 \mathrm{~g} / \mathrm{t}$ of Aero 725 and fuel oil ( $\mathrm{pH}=9 ; 65 \%$ solid) gave a low-grade concentrate assaying $15.1 \% \mathrm{P}_{2} \mathrm{O}_{5}$ with a recovery rate of $76.8 \%$. Pease et al. [47] investigated the flotation performance of different size fractions and reported the poor floatability of fine material. Therefore, adding the 40-71 $\mu \mathrm{m}$ fraction to the flotation feed $(71-315 \mu \mathrm{m})$ might not be a good option.

\subsubsection{Scrubbing and Attrition}

Scrubbing-attrition treatment was used to improve the grade and recovery of phosphate from the $\mathrm{P}_{2} \mathrm{O}_{5}$ rich fraction $(71-315 \mu \mathrm{m})$. The results of the scrubbing test (Table 5) showed that the $\mathrm{P}_{2} \mathrm{O}_{5}$ grade and recovery are $13.5 \%$ and $34.3 \%$, respectively. The $\mathrm{P}_{2} \mathrm{O}_{5}$ content increased by $1.45 \%$, compared to the representative sample $(12.0 \%)$, even though this did not have a significant impact on the $\mathrm{CaO} / \mathrm{P}_{2} \mathrm{O}_{5}$ ratio (3.26), compared with that of the raw sample (3.39). $\mathrm{MgO}$ and $\mathrm{SiO}_{2}$ contents decreased from $4.67 \%$ to $3.8 \%$ and from $20.0 \%$ to $16.5 \%$, respectively. Cd concentration also decreased from $65 \mathrm{mg} / \mathrm{kg}$ (raw sample) to $55 \mathrm{mg} / \mathrm{kg}$. The scrubbing step has raised the content of $\mathrm{P}_{2} \mathrm{O}_{5}$ by the elimination of the impurities such as $\mathrm{MgO}, \mathrm{SiO}_{2}$ and $\mathrm{Cd}$. The coarse fraction $(+315 \mu \mathrm{m})$ represented $10.1 \%$ and $19.7 \%$ of the feed and phosphate value respectively. This fraction may be ball-milled and combined with the $-315+71 \mu \mathrm{m}$ fraction to constitute the feed to the flotation circuit. The fine fraction $(-71 \mu \mathrm{m})$ assays $11.5 \%$ of $\mathrm{P}_{2} \mathrm{O}_{5}$ and a recovery close to $45.9 \%$. Attrition was used to improve the separation efficiency of clay coatings from phosphate surface. Results of the scrubbing-attrition test are shown in Table 6. The 10 min-assay leads to a $\mathrm{P}_{2} \mathrm{O}_{5}$ grade (15.5\%) which is better than those obtained with 5 and 15 min assays (13.7\% and $14.4 \%$, respectively). 
Table 5. Chemical analysis of scrubbed sample.

\begin{tabular}{|c|c|c|c|c|c|c|c|c|}
\hline \multirow[t]{2}{*}{$\begin{array}{l}\text { Fraction } \\
(\mu \mathrm{m})\end{array}$} & \multirow[t]{2}{*}{$\begin{array}{c}\text { Weight } \\
\text { (\%) }\end{array}$} & \multicolumn{2}{|c|}{$\mathrm{P}_{2} \mathrm{O}_{5}(\%)$} & \multirow[t]{2}{*}{$\begin{array}{c}\mathrm{CaO} \\
(\%)\end{array}$} & \multirow[t]{2}{*}{$\mathrm{CaO} / \mathrm{P}_{2} \mathrm{O}_{5}$} & \multirow[t]{2}{*}{$\begin{array}{c}\mathrm{MgO} \\
(\%)\end{array}$} & \multirow[t]{2}{*}{$\begin{array}{c}\mathrm{SiO}_{2} \\
(\%)\end{array}$} & \multirow[t]{2}{*}{$\begin{array}{c}\mathrm{Cd} \\
(\mathrm{mg} / \mathrm{kg})\end{array}$} \\
\hline & & Grade & Recovery & & & & & \\
\hline+315 & 23.1 & 10.1 & 19.7 & 46.8 & 4.66 & 3.19 & 18.8 & 97 \\
\hline$-315+71$ & 30.0 & 13.5 & 34.3 & 43.8 & 3.26 & 3.80 & 16.5 & 55 \\
\hline-71 & 46.9 & 11.5 & 46.0 & 35.9 & 3.11 & 5.95 & 22.9 & 56 \\
\hline Reconstituted & 100 & 11.8 & 100 & 40.78 & 3.46 & 4.67 & 20.0 & 65.2 \\
\hline
\end{tabular}

Table 6. Chemical analysis after scrubbing and attrition treatments.

\begin{tabular}{ccccc}
\hline \multirow{2}{*}{ Time (min) } & \multirow{2}{*}{ Fraction $(\boldsymbol{\mu m})$} & \multirow{2}{*}{ Weight $(\%)$} & \multicolumn{2}{c}{$\mathbf{P}_{\mathbf{2}} \mathbf{O}_{\mathbf{5}}(\mathbf{\%})$} \\
\cline { 4 - 5 } & & & Grade & Recovery \\
\hline 5 & $-315+71$ & 88.8 & 13.7 & 90.6 \\
10 & $-315+71$ & 84.2 & 15.5 & 97.2 \\
15 & $-315+71$ & 86.6 & 14.4 & 92.4 \\
\hline
\end{tabular}

The scrubbed-attrited 71-315 $\mu \mathrm{m}$ fraction was used for HLS tests, in order to assess the "pure phase" of phosphate, which corresponds to the optimum concentration of $\mathrm{P}_{2} \mathrm{O}_{5}$ that can be achieved through enrichment methods. Results of HLS and identification of phosphate grains, under the binocular microscope, are shown in Table 7. The highest grade of $\mathrm{P}_{2} \mathrm{O}_{5}(30.9 \%)$ achieved by HLS, is the maximum concentration that can be obtained by physical or physicochemical separation processes. $\mathrm{CaO}$ is high $(49.5 \%)$, showing that the carbonates are included into the phosphate particles (endogangue), which is in agreement with the petrographic observations. A high content of $\mathrm{CaO}$ in the phosphate concentrate may increase the consumption of sulfuric acid during the production of phosphoric acid [48]. Cd concentration $(27 \mathrm{mg} / \mathrm{kg})$ is significantly lower than that of the representative raw sample $(65 \mathrm{mg} / \mathrm{kg})$ and the scrubbed one $(55 \mathrm{mg} / \mathrm{kg})$. Therefore, it can be stated that cadmium is more concentrated in the exogangue of the studied phosphates.

Table 7. Results of the chemical analysis of pure phosphate phase recovered by HLS.

\begin{tabular}{ccccccc}
\hline Element & $\mathbf{P}_{\mathbf{2}} \mathrm{O}_{\mathbf{5}}(\%)$ & $\mathrm{CaO}(\%)$ & $\mathrm{CaO} / \mathrm{P}_{\mathbf{2}} \mathrm{O}_{5}$ & $\mathrm{MgO}(\%)$ & $\mathrm{SiO}_{\mathbf{2}}(\%)$ & $\mathrm{Cd}(\mathrm{mg} / \mathbf{k g})$ \\
\hline Concentration & 30.9 & 49.5 & 1.60 & 1.09 & 2.22 & 27 \\
\hline
\end{tabular}

\subsubsection{Grinding}

According to Anglaret et al. [38], the rotation speed should be between 65 and $80 \%$ of the critical rotational speed (Vcr) of the mill. The critical rotational speed is calculated on the basis of the equation:

$$
\mathrm{V}_{\mathrm{cr}}=32 / \sqrt{\mathrm{D}}
$$

where $\mathrm{D}$ is the diameter of the grinding cell expressed in meters. The diameter of the mill, used in this study, is equal to $0.25 \mathrm{~m}$, which corresponds to a critical rotational speed of $64 \mathrm{rpm}$; the rotation speed $\mathrm{V}$ varies according to the following range: $41.6<\mathrm{V}<51.2$. The rotation speed chosen for this study is $50 \mathrm{rpm}$.

Effect of the Grinding Time on the Grade and Recovery of $\mathrm{P}_{2} \mathrm{O}_{5}$

Grinding tests were evaluated at 2, 3 and $4 \mathrm{~min}$ after fixing the rotation speed at $50 \mathrm{rpm}$, solid concentration at $40 \%$ and charge ratio at $5 / 1$. Results (Table 8 ) have shown that the best outcome for $\mathrm{P}_{2} \mathrm{O}_{5}$ grade and recovery was obtained after a 4 min-grinding period. This optimal grinding time was chosen for the rest of the tests. 
Effect of the Charge Ratio on the Grade and Recovery of $\mathrm{P}_{2} \mathrm{O}_{5}$

The following charge ratio was studied: $3 / 1,4 / 1$ and $5 / 1$ after fixing rotation speed at $50 \mathrm{rpm}$, solid concentration at $40 \%$ and grinding time at $4 \mathrm{~min}$. The results displayed in Table 8 show that the best outcome for $\mathrm{P}_{2} \mathrm{O}_{5}$ grade and recovery was obtained by using the charge ratio $5 / 1$. This optimal ratio was chosen for the rest of the tests.

Effect of Solid Concentration on the Grade and Recovery of $\mathrm{P}_{2} \mathrm{O}_{5}$

Grinding tests with 30\%, 40\% and 50\% solids were evaluated after fixing the rotation speed at $50 \mathrm{rpm}$, charge ratio at 5/1 and grinding time at $4 \mathrm{~min}$. Results, displayed in Table 8, show that the best results in term of grade and recovery of $\mathrm{P}_{2} \mathrm{O}_{5}$ were obtained for $40 \%$ solids.

\section{Optimum Grinding Parameters}

The optimum grinding parameters are rotation speed (Rs) of $50 \mathrm{rpm}$, charge ratio $(\mathrm{Cr})$ of $5 / 1$, solid concentration (Sc) of $40 \%$ and a grinding time (Gt) equal to $4 \mathrm{~min}$. These parameters allowed us to improve the separation of phosphate grains from their gangue. The optimal test has shown (Table 9) an improvement in $\mathrm{P}_{2} \mathrm{O}_{5}$ content, from $10.1 \%$ (before grinding) to $14.5 \%$. The $71-315 \mu \mathrm{m}$ fraction released after grinding was subjected to attrition treatment by using the same parameters as the ones employed for the scrubbed fraction (see Section 3.4.1). This step has made it possible to improve the $\mathrm{P}_{2} \mathrm{O}_{5}$ content from $14.5 \%$ to $15.2 \%$ (Table 9). Grinding causes modifications in terms of grain texture, morphology, surface chemistry, and electrical-surface charge [49]. The increase of the grain-surface area may increase the reactivity with the flotation reagents [50].

Table 8. Grinding tests results after variation of different parameters.

\begin{tabular}{|c|c|c|c|c|c|c|c|c|}
\hline \multirow{2}{*}{$\begin{array}{c}\text { Parameter to Be } \\
\text { Varied }\end{array}$} & \multirow{2}{*}{ Test } & \multirow{2}{*}{$\begin{array}{l}\text { Time } \\
\text { (min) }\end{array}$} & \multirow{2}{*}{$\mathrm{Cr}$} & \multirow{2}{*}{ Sc $(\%)$} & \multirow{2}{*}{$\begin{array}{c}\text { Rotation } \\
\text { Speed (Rpm) }\end{array}$} & \multirow{2}{*}{$\begin{array}{c}\text { Weight } \\
(\%)\end{array}$} & \multicolumn{2}{|c|}{$\mathrm{P}_{2} \mathrm{O}_{5}(\%)$} \\
\hline & & & & & & & Grade & Recovery \\
\hline \multirow{3}{*}{ Grinding time $(\mathrm{Gt})$} & 1 & 2 & $5 / 1$ & 40 & 50 & 28.1 & 14.2 & 39.7 \\
\hline & 2 & 3 & $5 / 1$ & 40 & 50 & 32.9 & 14.4 & 47.0 \\
\hline & 3 & 4 & $5 / 1$ & 40 & 50 & 40 & 14.5 & 57.6 \\
\hline \multirow{3}{*}{ Charge ratio $(\mathrm{Cr})$} & 1 & 4 & $3 / 1$ & 40 & 50 & 29.8 & 14.4 & 42.6 \\
\hline & 2 & 4 & $4 / 1$ & 40 & 50 & 30 & 14.4 & 43.1 \\
\hline & 3 & 4 & $5 / 1$ & 40 & 50 & 40.2 & 14.5 & 58.1 \\
\hline \multirow{3}{*}{$\begin{array}{l}\text { Solid concentration } \\
\text { (Sc) }\end{array}$} & 1 & 4 & $5 / 1$ & 30 & 50 & 28.6 & 14.4 & 40.9 \\
\hline & 2 & 4 & $5 / 1$ & 40 & 50 & 40.2 & 14.5 & 58.0 \\
\hline & 3 & 4 & $5 / 1$ & 50 & 50 & 31.2 & 14.4 & 44.7 \\
\hline
\end{tabular}

Table 9. Grade and recovery of $\mathrm{P}_{2} \mathrm{O}_{5}$ after optimum grinding and attrition tests.

\begin{tabular}{cccccc}
\hline \multirow{2}{*}{ Experiment } & \multirow{2}{*}{ Fraction $(\boldsymbol{\mu \mathrm { m } )}$} & \multirow{2}{*}{ Weight $(\mathbf{\%})$} & \multicolumn{2}{c}{$\mathbf{P}_{\mathbf{2}} \mathbf{O}_{\mathbf{5}} \mathbf{( \% )}$} & \multirow{2}{*}{ CaO (\%) } \\
\cline { 4 - 5 } & & & Grade & Recovery & \\
\hline \multirow{2}{*}{ Grinding } & $>315$ & 33.7 & 6.71 & 22.5 & 47.8 \\
& $71-315$ & 40.2 & 14.5 & 58.0 & 46.5 \\
& $<71$ & 26.1 & 5.45 & 14.1 & 44.8 \\
\hline \multirow{2}{*}{ Attrition } & $71-315$ & 87.2 & 15.2 & 91.4 & 46.8 \\
\hline
\end{tabular}

\subsubsection{Flotation}

Flotation tests using anionic/cationic collectors [26,51,52] were applied on the 71-315 $\mu \mathrm{m}$ fractions resulting from sizing, washing, grinding and attrition treatments (Figure 4). The flotation feed contains (Table 10) $15.5 \%$ of $\mathrm{P}_{2} \mathrm{O}_{5}$ and $3.39 \% \mathrm{MgO}$ with a very high $\mathrm{CaO} / \mathrm{P}_{2} \mathrm{O}_{5}$ ratio (2.9). $\mathrm{SiO}_{2}$ content $(13.2 \%$ ) is low compared to the representative raw phosphate sample $(20.5 \%)$ since silicates are preferably 
associated to the fine fraction. The latter has been reduced by sieving, scrubbing and attrition. During the flotation tests, two parameters were varied: the $\mathrm{pH}$ of the pulp and reagents. The siliceous gangue floated at a natural $\mathrm{pH}$ by means of a cationic collector [14]. Carbonates are recovered at acidic $\mathrm{pH}$ with the anionic collector which operates, at the same time, as an activator of silicates [39]. Phosphate makes the non-floating fraction, which is recovered in acidic $\mathrm{pH}$ [31], and in the presence of phosphoric acid, which is the most recommended depressant during calcite flotation [34,53,54]. The content of the major elements in the final products of the optimal flotation test is summarized in Table 10. Tailings are removed as a froth 1 (21.3\% weight: silicates > carbonates) and a froth 2 (25.3\% weight: carbonates $>$ silicates). The $\mathrm{CaO} / \mathrm{P}_{2} \mathrm{O}_{5}$ ratio is still high (1.71) compared to the ratio required for industrial application $\left(\mathrm{CaO} / \mathrm{P}_{2} \mathrm{O}_{5}<1.6\right.$; [44]. Initially, such a ratio could be attributable to the presence of carbonates included in the phosphate grains, a hypothesis confirmed by Zidi et al. [26] in the study of the low-grade phosphate discharged by the Kef Eddour washing plant. Nevertheless, part of the floated carbonates could result from the similarity of their surface chemical propriety with respect to apatite, which makes their separation rather difficult [33,53]. The contents of $\mathrm{SiO}_{2}(2.52 \%)$ and $\mathrm{MgO}$ $(1.03 \%)$ show a noticeable decrease compared to the flotation feed (13.2\% and $3.39 \%$, respectively). The valuable ore ( $53.4 \%$ weight) is recovered as non-floating phosphate concentrate assaying $27.1 \%$ $\mathrm{P}_{2} \mathrm{O}_{5}$ with a recovery rate of $92.4 \%$.

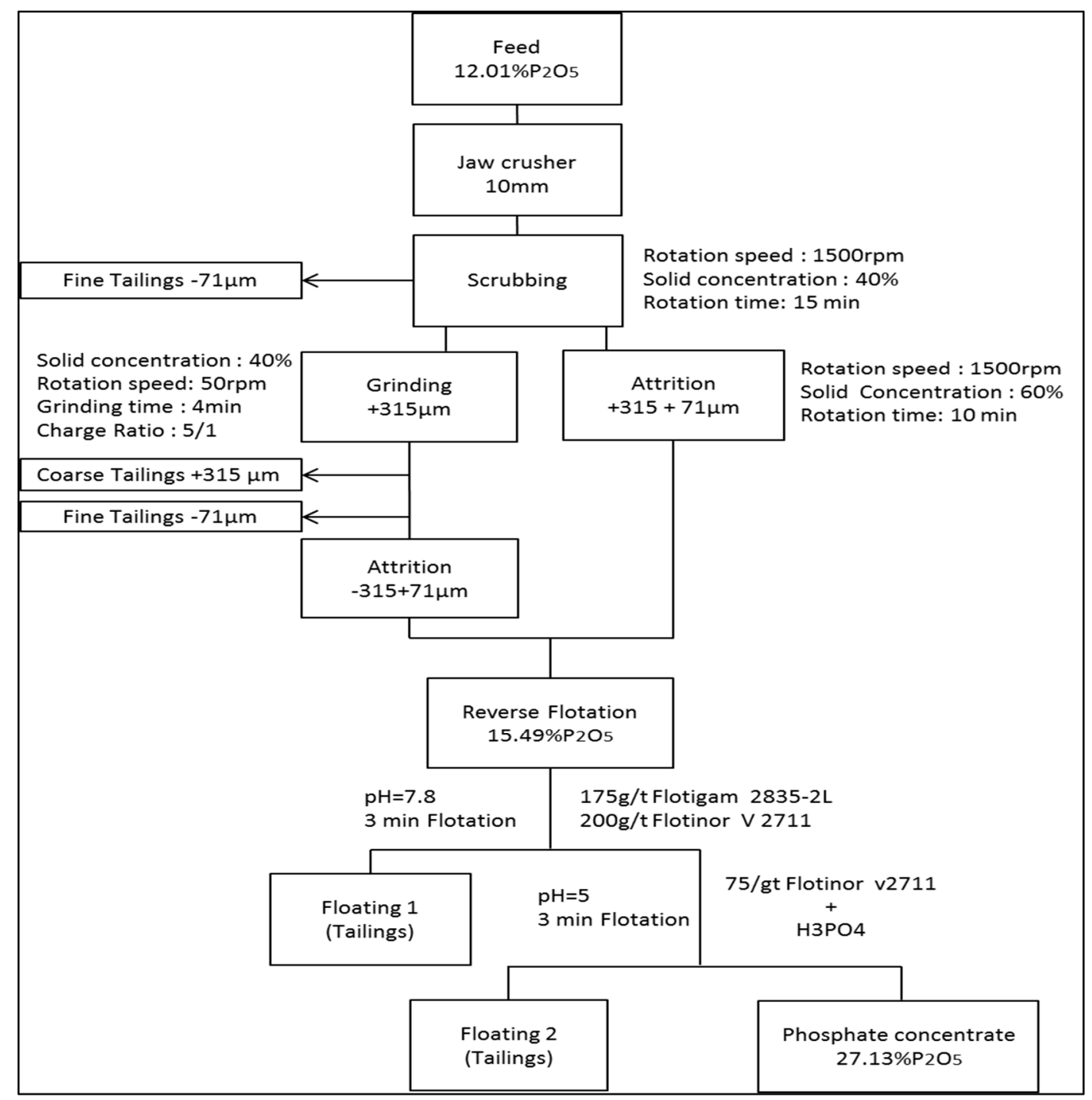

Figure 4. Proposed flow sheet for the valorization of the studied low-grade phosphates. 
Table 10. Results of chemical analysis of the flotation feed and the flotation test products.

\begin{tabular}{|c|c|c|c|c|c|c|c|}
\hline \multirow{2}{*}{ Product } & \multirow{2}{*}{$\begin{array}{c}\text { Weight } \\
\text { (\%) }\end{array}$} & \multicolumn{2}{|c|}{$\mathrm{P}_{2} \mathrm{O}_{5}(\%)$} & \multirow{2}{*}{$\mathrm{CaO}(\%)$} & \multirow{2}{*}{$\mathrm{CaO} / \mathrm{P}_{2} \mathrm{O}_{5}$} & \multirow{2}{*}{$\begin{array}{c}\mathrm{MgO} \\
(\%)\end{array}$} & \multirow{2}{*}{$\begin{array}{c}\mathrm{SiO}_{2} \\
(\%)\end{array}$} \\
\hline & & Grade & Recovery & & & & \\
\hline Flotation feed & - & 15.5 & - & 44.6 & 2.9 & 3.39 & 13.2 \\
\hline Floating 1 (Tailings) & 21.3 & 3.23 & 4.40 & 36.6 & 11.3 & 5.96 & 26.0 \\
\hline Floating 2 (Tailings) & 25.3 & 2.01 & 3.20 & 47.2 & 23.5 & 4.89 & 23.9 \\
\hline $\begin{array}{c}\text { Non-floating } \\
\text { (Phosphate-concentrate) }\end{array}$ & 53.4 & 27.1 & 92.4 & 46.5 & 1.71 & 1.03 & 2.52 \\
\hline Reconstituted & 100 & 15.7 & 100 & 44.6 & 2.80 & 3.05 & 12.9 \\
\hline
\end{tabular}

\section{Conclusions}

Phosphates of the Tozeur-Nefta roof series have, so far, been rejected as non-profitable material. This study has revealed that this material is a low-grade ore $\left(12.0 \% \mathrm{P}_{2} \mathrm{O}_{5}\right)$ with siliceous and carbonated gangue. Beneficiation assays (sizing, scrubbing-attrition, grinding and flotation) were conducted on the $+71 \mu \mathrm{m}$ fraction of this material. Scrubbing followed by attrition of the $71-315 \mu \mathrm{m}$ fractions to improve the grade to $15.5 \% \mathrm{P}_{2} \mathrm{O}_{5}$. The $+315 \mu \mathrm{m}$ fractions were wet-grounded and sieved to $71-315 \mu \mathrm{m}$ and floated altogether with the fraction $71-315 \mu \mathrm{m}$, as yielded by scrubbing-attrition. Reverse-flotation tests conducted on the phosphate-rich fraction $(71-315 \mu \mathrm{m})$ have made it possible to enhance the grade from $15.5 \%$ to $27.1 \% \mathrm{P}_{2} \mathrm{O}_{5}$ with a recovery of $92.4 \%$. The results of the enrichment tests that were carried out are considered satisfactory as long as they have allowed the beneficiated poor-raw phosphate material to reach the levels of marketable grades. As a result, we believe that the flow sheet developed at the end of this study can be directly applied on an industrial scale.

Author Contributions: F.S. and H.B.; Methodology, H.B., G.D. and H.T.; Investigation, H.B., G.D. and H.T.; Resources, R.S., N.F., N.C., G.D. and H.T.; Writing-Original Draft Preparation, H.B., G.D. and H.T.; WritingReview \& Editing, F.S. and R.S.; Supervision, F.S., R.S., N.F. and N.C.; Project Administration, F.S.

Funding: This research received no external funding.

Acknowledgments: The authors owe a great appreciation to Compagnie des Phosphates de Gafsa (CPG) for all the facilities granted to the sampling campaign as well as the mineralogical (Haithem Mansouri) and chemical analysis (Sahbi Harakati). The manuscript benefited from thorough critical appraisal by Bousairi Boujlel, former Central Research Director of CPG. In addition, we thank Faysal Souissi, English Department, College of Humanities of Tunis, University of Tunisia, for his kind and thorough review of the English version of this manuscript.

Conflicts of Interest: The authors declare no conflict of interest.

\section{References}

1. Galfati, I. Etude de l'impact des rejets de l'industrie Phosphatière sur l'environnement dans le bassin de Gafsa Métlaoui. Ph.D. Thesis, University of Tunis El Manar, Tunis, Tunisia, 2010.

2. IFDC. Available online: https://ifdc.org/wp-content/uploads/2015/03/100922_kauwenbergh_ presentation_0.pdf (accessed on 14 September 2018).

3. Burollet, P.F. Contribution à l'étude stratigraphique de la Tunisie centrale. Ann. Mines Geol. 1956, 18, 1-350.

4. Sassi, S. La sédimentation phosphatée au Paléocène dans le Sud et le Centre oust de la Tunisie. Ph.D. Thesis, Université d'Orsay, Paris-Sud, France, 1974.

5. Chaabani, F. Dynamique de la partie orientale du bassin de Gafsa au crétacé et au paléogène. Etude minéralogique et géochimique de la série phosphatée éocène (Tunisie méridionale). Ph.D. Thesis, University of Tunis El Manar, Tunis, Tunisia, 1995.

6. Zaier, A. Evolution tecto-sédimentaire du bassin phosphate du Centre-Ouest de la Tunisie, minéralogie, pétrographie, géochimie et genèse des phosphorites. Ph.D. Thesis, University of Tunis El Manar, Tunis, Tunisia, 1999.

7. Bel Haj Khalifa, M. Etude géostatistique du gisement de phosphates multicouches de Nefta-Tozeur (Tunisie). Ph.D. Thesis, University of Tunis El Manar, Tunis, Tunisia, 1996. 
8. Ben Hassen, A. Données nouvelles sur la matière organique associée aux séries du bassin phosphaté du sud-tunisien (Gisement de Ras-Draâ) et sur la phosphatogenèse. Ph.D. Thesis, Université d' Orléans, Orléans, France, 2007.

9. Ben Hassen, A.; Trichet, J.; Disnar, J.R.; Belayouni, H. Données nouvelles sur le contenu organique des dépôts phosphatés du gisement de Ras-Draâ (Tunisie). C. R. Geosci. 2009, 341, 319-326. [CrossRef]

10. Ben Hassen, A.; Trichet, J.; Disnar, J.R.; Belayouni, H. Pétrographie et géochimie comparées des pellets phosphatés et de leur gangue dans le gisement phosphaté de Ras-Draâ (Tunisie). Implications sur la genèse des pellets phosphatés. Swiss J. Geosci. 2010, 103, 457-473. [CrossRef]

11. Gallala, W.; Saïdi, M.; El Haji, S.; Zayani, K.; Gaied, M.E.; Montacer, M. Characterization and Valorization of Tozeur-Nefta Phosphate Ore Deposit (Southwestern Tunisia). Procedia Eng. 2016, 138, 8-18. [CrossRef]

12. El-Jallad, I.S.; Abouzeid, A.Z.; El-Sinbawy, H.A. Calcination of phosphates: Reactivity of calcined phosphate. Powder Technol. 1980, 26, 187-197. [CrossRef]

13. Zafar, Z.I.; Anwar, M.M.; Pritchard, D.W. Optimization of thermal beneficiation of a low-grade dolomitic phosphate rock. Int. J. Miner. Process. 1995, 43, 123-131. [CrossRef]

14. Mohammad Khani, M.; Noaparast, M.; Shafaei, S.Z.; Amini, A.; Amini, E.; Abdollahi, H. Double reverse flotation of a very low-grade sedimentary phosphate rock, rich in carbonate and silicate. Int. J. Miner. Process. 2011, 100, 157-165. [CrossRef]

15. Good, P.C. Beneficiation of Unweathered Indian Calcareous Phosphate Rock by Calcination and Hydration; US Bureau of Mines: Washington, DC, USA, 1976.

16. Hollick, C.T.; Wright, R. Recent trends in phosphate mineral beneficiation. Trans. Inst. Min. Metall. Sect. A 1986, 95, 150-154.

17. Rao, T.C.; Rao, L.S.; Rao, G.M. Beneficiation of Indian Low-Grade Phosphate Deposits-Problems and Prospects. Trans. Indian Inst. Met. 1992, 45, 195-205.

18. Van Straaten, P. Rocks for Crops: Agrominerals of Sub-Saharan Africa; ICRAF: Nairobi, Kenya, 2002; ISBN 0-88955-512-5.

19. Woodrooffe, H.M. Phosphate in the Kola Peninsula, USSR. Miner. Eng. 1972, 24, 54-56.

20. Blazy, P.; Jdid, E.A. Calcination du phosphate sédimentaire à gangue carbonatée d'Akashat (Irak) en four rotatif et en four éclair (Flash). C. R. Acad. Sci 1997, 325, 761-764. [CrossRef]

21. Bangar, K.C.; Yadav, K.S.; Mishra, M.M. Transformation of rock phosphate during composting and the effect of humic acid. Plant Soil 1985, 25, 259-266. [CrossRef]

22. Sadeddin, W.; Abu-Eishah, S.I. Minimization of free calcium carbonate in hard and medium-hard phosphate rocks using dilute acetic acid solution. Int. J. Miner. Process. 1990, 30, 113-125. [CrossRef]

23. Abu-Eishah, S.I.; Muthaker, M.; Touqan, N. A new technique for the beneficiation of low-grade carbonate-rich phosphate rocks by digestion with dilute acetic acid solutions: Pilot plant testing results. Miner. Eng. 1991, 4, 573-586. [CrossRef]

24. Ibrahim, S.S.; El Kammar, A.M.; Guda, A. Characterization and separation of pyrite from Abu Tartur black shale. Int. J. Min. Sci. Technol. 2015, 25, 565-571. [CrossRef]

25. Mâamri, A.J.; Abbassi, L.; Batis, H.N. Characterization of the Oum El Khacheb phosphorites (South Tunisia) and enrichment of big rejections by grinding. Int. J. Min. Sci. Technol. 2016, 26, 833-842. [CrossRef]

26. Zidi, R.; Babbou-Abdelmalek, C.; Chaabani, F.; Abbassi, L. Enrichment of low-grade phosphate coarse particles by froth-flotation process, at the Kef-Eddour washing plant, Tunisia. Arab. J. Geosci. 2016, 9, 462. [CrossRef]

27. Lawver, J.E.; Weigel, R.L.; Snow, R.E.; Hwang, C.L. Phosphate reserves enhanced by beneficiation. Min. Congr. $1982,68,27-31$.

28. Elgillani, D.A.; Abouzeid, A.Z. Flotation of carbonates from phosphate ores in acidic media. Int. J. Miner. Process. 1993, 38, 235-256. [CrossRef]

29. Abouzeid, A.Z.M. Physical and thermal treatment of phosphate ores-an overview. Int. J. Miner. Process. 2008, 85, 59-84. [CrossRef]

30. El-Midany, A.A. Separating dolomite from phosphate rock by reactive flotation: Fundamentals and application. Ph.D. Thesis, University of Florida, Gainesville, FL, USA, 2004.

31. Henchiri, A.; Cecile, J.L.; Baudet, G.; Barbery, G.; Bloise, R.U.S. Process of the treatment of phosphate ores with silico-carbonate gangue. U.S. Patent 4,324,653, 13 April 1982.

32. Houot, R. Beneficiation of phosphatic ores through flotation: Review of industrial applications and potential developments. Int. J. Miner. Process. 1982, 9, 353-384. [CrossRef] 
33. Abdel-Khalek, N.A. Evaluation of flotation strategies for sedimentary phosphates with siliceous and carbonates gangues. Miner. Eng. 2000, 13, 789-793. [CrossRef]

34. Abouzeid, A.Z.; Negm, A.T.; Elgillani, D.A. Upgrading of calcareous phosphate ores by flotation: Effect of ore characteristics. Int. J. Miner. Process. 2009, 90, 81-89. [CrossRef]

35. Lisiansky, L.; Baker, M.; Larmour-Ship, K.; Elyash, O. A Tailor Made Approach for the Beneficiation of Phosphate Rock. In Beneficiation of Phosphates; Zhang, P., Miller, J.B., Wingate, E., Filho, L.L., Eds.; SME CO.: Englewood, CO, USA, 2016; pp. 55-61. ISBN 978-0-87335-427-1.

36. Liu, X.; Zhang, Y.; Liu, T.; Cai, Z.; Sun, K. Characterization and Separation Studies of a Fine Sedimentary Phosphate Ore Slime. Minerals 2017, 7, 94. [CrossRef]

37. Somasundaran, P.; Lin, I.J. Effect of the Nature of Environment on Comminution Processes. Ind. Eng. Chem. Process. Des. Dev. 1972, 11, 321-331. [CrossRef]

38. Anglaret, P.; Filippi, J.; Kazmierczak, S. Technologie Génie Chimique, Tome I; CRDM: Amiens, France, 1998; pp. 17-384. ISBN 2-86615-223-9.

39. Houot, R.; Joussemet, R.; Tracez, J.; Brouard, R. Selective flotation of phosphatic ores having a siliceous and/or a carbonated gangue. Int. J. Miner. Process. 1985, 14, 245-264. [CrossRef]

40. Henchiri, A. A contribution to carbonates-phosphate separation by flotation technique. In Beneficiation of Phosphate: Theory and Practice; El-Shall, H., Moudgil, R., Wiegel, R., Eds.; SME: Littleton, CO, USA, 1993; pp. 225-243.

41. Baudet, G.; Save, M. Phosphoric esters as carbonate collectors in the flotation of sedimentary phosphate ores. In Beneficiation of Phosphates: Advances in Research and Practice; Zhang, P., El-Shall, H., Wiegel, R., Eds.; SME: Littleton, CO, USA, 1999; pp. 163-185.

42. Blazy, P. La valorisation des Minerais: Manuels de Minéralurgie; Presses Universitaires de France: Vendôme, France, 1970; pp. 5-415.

43. Sengul, H.; Ozer, A.K.; Gulaboglu, M.S. Beneficiation of Mardin-Mazıdaği (Turkey) calcareous phosphate rock using dilute acetic acid solutions. Chem. Eng. J. 2006, 122, 135-140. [CrossRef]

44. Becker, P. Phosphates and Phosphoric Acid: Raw Materials, Technology, and Economics of the Wet Process; Marcel Dekker: New York, NY, USA, 1989; pp. 1-579. ISBN 0-8247-1712-0.

45. Khelifi, L. Contribution à l'étude géochimique des phosphates du bassin de Gafsa-Metlaoui. Exemple du gisement d'Oum Lakhcheb. Master's Thesis, University of Tunis El Manar, Tunis, Tunisia, 2012.

46. Galfati, I.; Bilal, E.; Abdallah, H.; Beji-Sassi, A. Geochemistry of solid effluents and phosphate ore washed from Metlaoui-Gafsa basin, Tunisia. Rom. J. Miner. Depos. 2014, 87, 83-86.

47. Pease, J.D.; Curry, D.C.; Young, M.F. Designing flotation circuits for high fines recovery. Miner. Eng. 2016, 19, 831-840. [CrossRef]

48. Al-Fariss, T.F.; El-Aleem, F.A.A.; El-Nagdy, K.A. Beneficiation of Saudi phosphate ores by column flotation technology. J. King Saud Univ. Sci 2013, 25, 113-117. [CrossRef]

49. Clerc, L. Broyage ultrafin de carbonates naturels: Paramétrisation, modélisation et conséquences physico-chimiques. Ph.D. Thesis, Ecole Nationale Supérieure des Mines, Saint-Etienne, France, 1983.

50. Bafghi, M.S.; Emami, A.H.; Zakeri, A.; Khak, J.V. Development and verification of a mathematical model for variations of the specific surface area of mineral powders during intensive milling. Powder Technol. 2010, 197, 87-90. [CrossRef]

51. Jian, T.; Longhua, X.; Wei, D.; Hao, J.; Zhiyong, G.; Yuehua, H. Adsorption mechanism of new mixed anioniccationic collectors in a spodumene-Feldspar flotation system. Chem. Eng. Sci. 2017, 164, 99-107. [CrossRef]

52. Houqin, W.; Jia, T.; Longhua, X.; Shuai, F.; Zhenye, Z.; Ruan, C. Flotation and adsorption of new mixed anionic/cationic collector in the spodumene-feldspar system. Miner. Eng. 2018, 127, 42-47. [CrossRef]

53. Amankonah, J.O.; Somasundaran, P. Effects of dissolved mineral species on the electrokinetic behavior of calcite and apatite. Colloids Surf. 1985, 15, 335-353. [CrossRef]

54. Hsieh, S.S.; Lehr, J.R. Beneficiation of dolomitic Idaho phosphate rock by the TVA diphosphoric acid depressant process. Min. Metall. Explor. 1985, 12, 10-13. [CrossRef]

(C) 2018 by the authors. Licensee MDPI, Basel, Switzerland. This article is an open access article distributed under the terms and conditions of the Creative Commons Attribution (CC BY) license (http:/ / creativecommons.org/licenses/by/4.0/). 